4. On the Genus Myosorex, with Description of a new Species from the Rio del Rey (Cameroons) District. By G. E. Dobson, M.A., F.R.S.

[Received November 8, 1887.]

The genus Myosore $x^{1}$ was founded in 1837 by Dr. J. E. Gray for the reception of a small species of white-toothed Shrew, Sorex varius, Smuts, from the Cape Colony ; which was then at once distinguished from all other known species of white-toothed Shrews by the short, subequal, and rather coarse hairs covering the tail. Trivial as this character may appear, and as such it has evidently been hitherto regarded by systematic zoologists, it is; however, the only one out of the many enumerated in the original definition of this genus (see footnote below) which is really characteristic of it taken in connection with the white colour of the teeth.

\title{
Myosorex.
}

Myosorex, Gray, Proc. Zool. Soc. 1837, p. 124.

General characters those of Crocidura, but distinguished by the absence of long hairs on the tail, which is clothed with short fur of equal or subequal length, by the shortness of the third upper incisor, and by the absence of a distinct cloaca, the generative organs and the alimentary canal opening on the surface close together by distinct orifices.

Dentition : $\frac{\text { Inc. } 3-3, \text { pm. } 3-3, \text { m. } 3-3}{\text { Mand. } 6-6 \text { or } 7-7}=30$ or 32 teeth.

Range. Africa south of the Sahara Desert.

\section{Myosorex varius.}

Sorex varius, Smuts, Mamm. Capens. 1832, p. 8.

Myosorex varius, Gray, Proc. Zool. Soc. 1837, p. 124.

This, the largest species of the genus, is somewhat larger than Crocidura aranea. The body is clothed with dense fur, pale reddish grey on the surface, passing gradually into ashy beneath, the basal four-fifths of the hairs bluish; tail clothed thinly with equal-sized reddish-grey hairs forming a small pencil at the tip. The lateral gland is well developed in males, rudimentary or absent in females, and situated close behind the arm.

The teeth are very peculiar and characteristic. The upper incisors and premolars are provided with prominent basal processes, the third

1 "Mrosorex, Gray. Head elongate, ears hid under the soft fur; tail elongate, slender, covered with short, rigid, close-pressed hairs, when old quadrangular; feet and toes not ciliated; teeth white; cutting-teeth $\frac{8}{6}$, two upper central unequally bifid, the second lateral moderate, the third very small, rudimentary, the fourth small but larger than the third; front lower cuttingteeth elongate, with an entire sharp upper edge; second and third lateral teeth small, simple, erowded on the base of the front ones."-Gray, P. Z. S. 1837, p. 124. 
incisor is much smaller than the anterior maxillary tooth, and the penultimate premolar is minute, quite invisible from without, and placed in the small angle between the adjoining teeth. The most remarkable peculiarity, however, is found in the mandible, where (as first pointed out by me in the Journ. Anat. Phys. xx. p. 359, 1886) a minute tooth exists on each side between the second and third teeth, so that the number of mandibular teeth is fourteen instead of twelve, as we find in all other known species of Soricida.

(For measurements see table p. 578.)

Hab. South Africa (Namaqua-Land, Cape Colony, Natal).

\section{Myosorex MORIO.}

Crocidura morio, Gray, Proc. Zool. Soc. 1862, p. $180^{\mathrm{T}}$.

Smaller than Myosorex varius and about the size of a large specimen of Crocidura aranea, but distinguished at once, not only from all species of the genus, but also from all known species of Soricida, by the comparatively enormous size of the lateral gland ${ }^{2}$, which, in the male, occupies a circular space having a diameter of 9 millimetres, larger than the space occupied by the same gland in the Great Indian Musk-Shrew (Crocidura carulescens), and by the nakedness of the sides and abdomen below and behind these glands. Ears moderate, clothed with very short hairs; manus and pes covered with short hairs. Fur dark reddish brown above, and slightly paler beneath.

The first upper incisor is long, the anterior cusp much longer than the posterior, which, however, is well developed; the third incisor is shorter than the anterior maxillary tooth; but the greatest peculiarity exists in the comparatively large size of the penultimate premolar, which, viewed externally, though not half the size of the anterior maxillary tooth, stands quite in the tooth-row, and its cusp equals or slightly exceeds (in specimens in which it is not worn) the anterior basal cusp of the last premolar. The last upper molar is like that of Myosorex varius, larger than in the species of the genus Crocidura, its posterior part being as well developed as the corresponding tooth in that species. The first mandibular tooth has two very distinct notches as in Myosorex varius; the second tooth is unicuspidate and has this peculiarity that, instead of being placed almost altogether on the first tooth, its base very slightly overlies it ;

1 " Uniform rather brownish black, rather paler and browner beneath. Teeth white. Feet very slender, weak. Tail nearly as long as the body and head, very slender, annulated, covered with very short closely adpressed hair.

"Length of body and head, dry, $2 \frac{3}{4}$ inches ; tail, dry, 2 inches."-Gray, $l$. $c$.

It may be seen that it would be impossible from this description alone to identify not merely the species but even the genus, nevertheless, as the type, a skin, corresponds in all respects to the well-preserved specimen in alcohol from which I have taken my description of this species, I retain Dr. Gray's specific title.

${ }_{2}$ Having shown the glands in this species to Mr. G. A. Boulenger, he remarked that an integumentary gland occupies a corresponding position on each side of the body in several species of the genus Paludicola (Batrachia); of very large size in some species (P. bufonium, Bell, e.g.), in others of the same genus it is so small as to render it very difficult to say whether a gland exists or not. 
the third tooth has not the prominent anterior and posterior cusps so well developed in $\boldsymbol{M}$. varius. There is no minute tooth between the second and third mandibular teeth.

(For measurements see table p. 578.)

$\mathrm{Hab}$. Cameroon District, West Africa.

'The type, a skin with skull, was collected by Captain R. Burton, and is preserved in the British Museum (Natural History); a second specimen, a well-preserved example of an adult male, in alcohol, has formed the basis of the above description, and has furnished the measurements given in the table at p. 578 .

\section{Myosorex Johnstoni, n. sp.}

Very slightly larger than Crocidura etrusca, and therefore almost the smallest mammal known. The tail is even shorter than in that species, shorter than the body without the head, and clothed characteristically with short, even-sized hairs. The ears are moderate and clothed with very short hairs. Both the manus and pes are moderate in size, with short claws, and covered with thinly-spread short fur. As in $M$. morio there is a very large lateral gland in the male, but as no female specimen has yet been obtained, its condition in that sex is unknown. So far as can be ascertained from the inspection of a single male specimen preserved in alcohol the colour of the fur is dark brown above, slightly paler beneath.

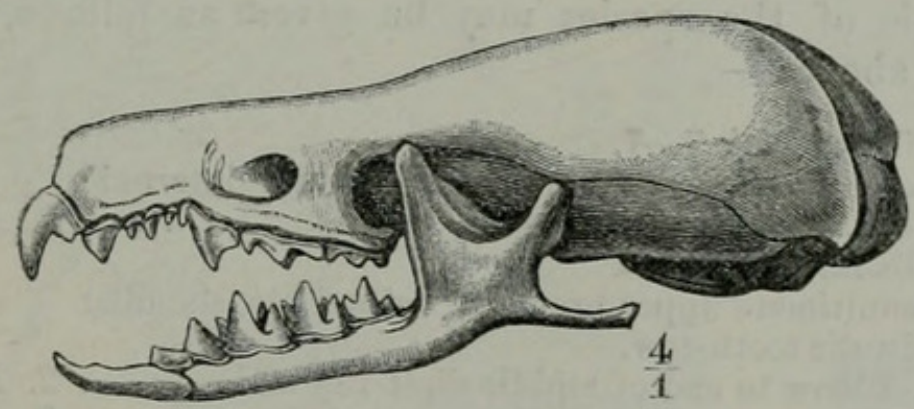

Skull of Myosorex johnstoni.

Although the animal is but slightly larger than $C$. etrusca in general measurements, yet its skull is considerably larger in all dimensions. The teetl agree with those of the other two species in the reduced size of the third upper incisor (see woodcut above), but correspond most closely with those of $M$. morio from the same part of Africa in their general form and in the position of the penultimate premolar, which stands in the tooth-row and is not minute as in $M$. varius. The anterior mandibular tooth has two notches, as in the other species, for the posterior basal cusp of the first upper incisor and for the cusp of the second incisor. There is no rudimentary tooth (such as I have described in M. varius) between the second and third mandibular teeth.

(For measurements see table p. 578.)

The type, a full-grown male specimen, well preserved in alcohol, was obtained by H. H. Johnston, Esq., H.M. Vice-Consul for the 
Cameroons, and I have much pleasure in connecting with its specific title the name of that distinguished traveller.

Hab. C'ameroon District, West Africa (Rio del Rey).

The following table exhibits the measurements, in millimetres, of adult male specimens (preserved in alcohol) of the three above described species; in the first column are those of Myosorex varius, in the second $M$. morio, and in the third M. johnstoni.

\begin{tabular}{|c|c|c|c|}
\hline & 1. & 2. & 3. \\
\hline Tip of nose to vent & 76 & 64 & 39 \\
\hline Vent to tip of tail ... & 41 & 55 & 25 \\
\hline 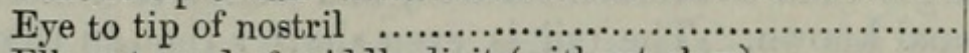 & $12 \frac{1}{2}$ & 12 & 9 \\
\hline Elbow to end of middle digit (without elaw) & 21 & $18 \frac{1}{2}$ & $11 \frac{1}{2}$ \\
\hline Manus (without claw)............................. & 9 & 8 & 5 \\
\hline 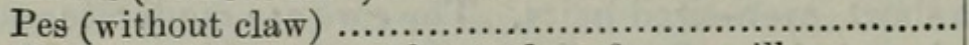 & $13 \frac{1}{2}$ & $13 \frac{1}{2}$ & 9 \\
\hline Skull, occipital crest to front edge of premaxilla....... & 19 & $16 \frac{1}{2}$ & 13 \\
\hline Skull, foramen magnum to front edge of premaxilla & 19 & $16 \frac{1}{2}$ & 12 \\
\hline Greatest width of the skull $\ldots \ldots \ldots \ldots \ldots \ldots \ldots \ldots \ldots$ & 11 & $9 \frac{1}{2}$ & 7 \\
\hline Length of upper tooth-row & $9 \frac{1}{2}$ & 8 & $6 \frac{1}{2}$ \\
\hline $\begin{array}{l}\text { Distance between tips of principal cusps of first upper } \\
\text { incisor and last premolar }\end{array}$ & $4 \frac{2}{2}$ & $4 \frac{1}{2}$ & $3 \frac{1}{2}$ \\
\hline Length of mandible from condyle to tip of first tooth ... & $14 \frac{i}{2}$ & 13 & $9 \frac{1}{2}$ \\
\hline
\end{tabular}

A synopsis of the species may be given as follows, from the descriptions above :-

A. Mandibular teeth 7-7.

a. Penultimate upper premolar minute, internal ; elbow to end of middle digit $21 \mathrm{~mm} \ldots \ldots \ldots \ldots \ldots . .1$......... varius.

B. Mandibular teeth 6-6.

$b$. Penultimate upper premolar not minute, standing in the tooth-row.

$b^{\prime}$. Elbow to end of middle digit $18 \frac{1}{2} \mathrm{~mm}$.

$c^{\prime}$. Elbow to end of middle digit $11 \frac{1}{2} \mathrm{~mm}$.

3 M. johnstoni.

5. On a new Species of Hyla from Port Hamilton, Corea, based on an example living in the Society's Gardens. By G. A. Boulenger, F.Z.S.

[Received July 2, 1887.]

\section{(Plate LI.)}

Two Tree-Frogs of the genus Hyla, obtained by Mr. George Stephen, of H.M.S. 'Champion,' at Port Hamilton, a small island between the Corean Peninsula and Japan, have been presented by him to the Society. They prove of great interest, as one belongs to a little-known race of Hyla arborea, viz. the var. japonica (Plate LI. fig. 2); and the other to a new species, which I propose to call, in honour of its discoverer. 


\section{$2 \mathrm{BHL}$ Biodiversity Heritage Library}

Dobson, G. E. 1887. "On the genus Myosorex, with description of a new species from the Rio del Rey (Cameroons) district." Proceedings of the Zoological Society of London 1887, 575-578.

View This Item Online: https://www.biodiversitylibrary.org/item/91212

Permalink: https://www.biodiversitylibrary.org/partpdf/67512

\section{Holding Institution}

Natural History Museum Library, London

\section{Sponsored by}

Natural History Museum Library, London

\section{Copyright \& Reuse}

Copyright Status: Public domain. The BHL considers that this work is no longer under copyright protection.

This document was created from content at the Biodiversity Heritage Library, the world's largest open access digital library for biodiversity literature and archives. Visit BHL at https://www.biodiversitylibrary.org. 